\title{
MARSH DEER (Blastocerus dichotomus) REINTRODUCTION IN THE JATAÍ ECOLOGICAL STATION (LUÍS ANTÔNIO, SP): SPATIAL PREFERENCES
}

\author{
FIGUEIRA, C. J. M., ${ }^{1,2}$ PIRES, J. S. R., ${ }^{2}$ ANDRIOLO, A., ${ }^{3}$ \\ COSTA, M. J. R. P. and DUARTE, J. M. B. ${ }^{4}$ \\ ${ }^{1} \mathrm{PG}$, Ecologia e Recursos Naturais, Universidade Federal de São Carlos, \\ Rodovia Washington Luís, km 235, CEP 13565-905, São Carlos, SP, Brazil \\ ${ }^{2}$ Laboratório de Análise e Planejamento Ambiental, Universidade Federal de São Carlos, \\ Rodovia Washington Luís, km 235, CEP 13565-905, São Carlos, SP, Brazil \\ ${ }^{3}$ Departamento de Zoologia, Instituto de Ciências Biológicas, Universidade Federal de Juiz-de-Fora, \\ CEP 36036-330, Juiz-de-Fora, MG, Brazil \\ ${ }^{4}$ Departamento de Zootecnia, Faculdade de Ciências Agrárias e Veterinária, UNESP, \\ Campus Jaboticabal, Rodovia Carlos Tonanni, km 5, CEP 14870-000, Jaboticabal, SP, Brazil \\ Correspondence to: Cassio José Montagnani Figueira, Rua São Domingos, 97, apto. 31, Ed. Ubatuba, \\ Centro, CEP 07110-080, Guarulhos, SP, Brazil, e-mails: pcassiof@iris.ufscar.br/cjmfigueira@hotmail.com \\ Received October 21, 2002 - Accepted January 8, 2004 - Distributed May 31, 2005
}

(With 3 figures)

\begin{abstract}
Throughout the latter half of the twentieth century, wildlife habitat destruction and species extinctions have greatly increased. As the number of endangered species grows, the use of reintroduction as a conservation tool against species extinction increases. This study focuses on a 16-month study on marsh deer reintroduced in the Jataí Ecological Station. The animals were radio tagged and tracked daily between December 1998 and April 2000. Displacement activity and spatial preferences were monitored by triangulation. The animals wandered the floodplains inside the protected area and also a floodplain that is part of privately owned property on the western edge of the Jataí Ecological Station. During the study, most of the reintroduced marsh deer preferred the private floodplain area more than the floodplains inside the protected area. This preference revealed the ecological importance of the area and the necessity of its incorporation into the Jataí Ecological Station.
\end{abstract}

Key words: marsh deer, spatial preference, reintroduction, radio tracking.

\section{RESUMO}

\section{Reintrodução de cervos-do-pantanal (Blastocerus dichotomus) na Estação Ecológica de Jataí (Luís Antônio-SP): uso do espaço}

A destruição dos habitats naturais e a extinção de espécies têm crescido muito a partir da última metade do século XX. Nesse contexto, o aumento do número de espécies ameaçadas tem proporcionado maior uso da reintrodução como estratégia de conservação no combate à atual taxa de extinção. O presente trabalho focaliza um estudo de 16 meses realizado com cervos-do-pantanal reintroduzidos na Estação Ecológica de Jataí. Os animais foram marcados com rádio-colares e monitorados diariamente entre dezembro de 1998 e abril de 2000, tendo suas atividades de deslocamento e uso do espaço acompanhadas por triangulação. Os animais exploraram várzeas dentro da unidade de conservação e também uma área de várzea pertencente a uma propriedade particular localizada na fronteira oeste da estação. Durante o período de estudo, a maioria dos cervos reintroduzidos utilizou a área de várzea particular mais intensivamente que as várzeas da unidade de conservação. A preferência demonstrada por essa área confirmou sua importância ecológica, evidenciando a necessidade de proteção por meio de sua incorporação aos limites da Estação Ecológica de Jataí.

Palavras-chave: cervo-do-pantanal, uso do espaço, reintrodução, radiotelemetria. 


\section{INTRODUCTION}

Conservation generally starts with identifying the causes of population decline and subsequently developing plans for protecting the threatened species. Among the possible steps included in such planning is animal translocation to protected areas (Green \& Rothstein, 1998).

Reintroduction can generally be considered as the translocation of any animal or vegetal specimen to a region inside the area of its original geographic distribution and, normally, in places wherein populations have declined significantly or disappeared entirely due to natural catastrophes or human interference (IUCN, 1984; Kleiman, 1989).

No register of marsh deer (Blastocerus dichotomus, Illiger 1811) (Mammalia, Cervidae) reintroduction is found in the literature. However, with respect to the ungulates, some success has been achieved as in the cases of the American bison (Bison bison), European bison (Bison bonasus) (Campbell, 1980; Conway, 1980), and white-tailed deer (Odocoileus virginianus) (Blackard, 1971), clearly demonstrating the potential of this strategy for conserving threatened species.

The marsh deer (Blastocerus dichotomus) is the largest Brazilian deer, reaching an average shoulder height of $1.3 \mathrm{~m}$ and an average weight of $100 \mathrm{~kg}$ for females and $130 \mathrm{~kg}$ for males (Duarte, 1996; Duarte \& Merino, 1997). Peculiar anatomical features such as interdigital membranes, extended hooves, and relatively long limbs denote its adaptation to flooding environments and other types of South American humid areas (Tomas et al., 1997). Despite the lack of specific studies on its social behavior, some information suggests that the marsh deer does not form large groups (Miller, 1930; Nogueira Neto, 1973; Schaller \& Vasconcelos, 1978; Tomas, 1986; Tomas, 1991; Beccaceci, 1994).

The original geographic distribution of the species extended from the southern Amazon Forest and west of the Atlantic Forest highlands to southern Rio Grande do Sul State, reaching the region of Pampas del Heath in Peru, eastern Bolivia, southern Paraguay, northeastern Argentina, and the extreme northern part of Uruguay (Azara, 1902; Ribeiro, 1919; Cabrera, 1961; Nogueira Neto, 1973; Jungius, 1976; Hofman et al., 1976). Currently, large populations of marsh deer can be observed only in restricted areas of the Brazilian Pantanal, the Bananal Island region, the Araguaia and Guaporé rivers, and the remaining floodplains of the Paraná River, placing the marsh deer on the list of Brazilian species threatened with extinction (Bernardes et al., 1990).

Multiple and complex factors have caused a marked retraction in the geographic distribution area of the species. More recently, the construction of large hydroelectric dams has become the main cause for the disappearance of natural marsh deer populations, since wide-scale loss of lowland habitats in the Neotropical region is an inevitable consequence of such constructions (Sioli, 1986; Gribel, 1993).

Marsh deer is practically extinct in São Paulo State, where it is classified as "critically endangered" (São Paulo, 1998). The last relevant population of this species was found on the floodplain of the Paraná river between the dams of Jupiá and Porto Primavera (Schaller \& Vasconcelos, 1978). This area, however, was flooded in 1998 by the Porto Primavera hydroelectric dam.

In view of this situation, we implemented the Porto Primavera Marsh Deer Project (Projeto Cervo-do-Pantanal de Porto Primavera) with a multifaceted proposal. Due to the urgent need of strategy definition if this species were to be conserved in São Paulo State, we developed the Marsh Deer Reintroduction Project (Projeto de Reintrodução do Cervo-do-Pantanal), designed to reintroduce marsh deer originating from the Porto Primavera population into the remaining floodplains in São Paulo State from which the original population had already disappeared. This study aimed to evaluate the spatial preferences presented by the reintroduced animals in the Jataí Ecological Station from December 1998 to April 2000.

\section{MATERIAL AND METHODS}

In 1998, five adult marsh deer were reintroduced in the Jataí Ecological Station, and released between December 22 and 31 according to methodology developed by Duarte et al. (in preparation). The reintroduced group, which presented negative serum tests for aftosa fever and had been immunized against parasitic diseases was composed of two males (M1 and M2) and three females (F1, F2, and F3).

The Jataí Ecological Station (protected area managed by the Instituto Florestal) is situated in Luís Antônio, São Paulo State $\left(21^{\circ} 33^{\prime} \mathrm{S} / 47^{\circ} 45^{\prime} \mathrm{W}\right.$ and $\left.21^{\circ} 37^{\prime} \mathrm{S} / 47^{\circ} 51^{\prime} \mathrm{W}\right)$. Its 9.010 ha are covered by cerrado vegetation and a rich aquatic ecosystem 
mosaic including low lands, streams, marginal lagoons, and floodplains of the Mogi-Guaçú river (Consema, 1985).

The floodplains (Sapé-Patos, Beija-Flor, Cafundó, and Infernão-Óleo) extend along the Mogi-Guaçú river and its tributary streams (Boa Sorte, Beija-Flor, and Cafundó) with a total area about 537 ha surrounded by cerrado, remaining bands of gallery forest, and sugarcane and other types of plantation, among other types of cultivated fields and privately-owned properties along the outer edges of the plains At the western border of the Jataí Ecological Station is a private floodplain area (named Capão-da-Cruz) surrounded by a sugarcane plantation. The floodplains inside the protected area and the private Capão-da-Cruz floodplain together total an area of about 2.049 ha (Fig. 1).

In itself (Table 1), the Sapé-Patos floodplain comprises an area of $129 \mathrm{ha}, 7 \mathrm{~km}$ in perimeter, and having a $0.71 \mathrm{~km}(0.18-1.27 \mathrm{~km})$ average width. The Beija-Flor floodplain consists of 75 ha, $11 \mathrm{~km}$ in perimeter with an average $0.20 \mathrm{~km}(0.08$ $0.46 \mathrm{~km}$ ) width; the Cafundó floodplain area includes $143 \mathrm{ha}$, having an average $0.40 \mathrm{~km}(0.20$ $0.70 \mathrm{~km}$ ) width and a $9 \mathrm{~km}$ perimeter. The InfernãoÓleo floodplain comprises a 190 ha area, $9 \mathrm{~km}$ in perimeter, and averaging $0.97 \mathrm{~km}(0.31-1.24 \mathrm{~km})$ in width. The privately owned Capão-da-Cruz floodplain has a 1,512 ha area, $50 \mathrm{~km}$ in perimeter and an average width of $1.75 \mathrm{~km}(0.47-3.52 \mathrm{~km})$.

Using products of Wildlife Materials Inc., the reintroduced animals were radio tagged and tracked with a TR-2 Telonics receiver connected to an $\mathrm{H}$ Telonics directional antenna (150,000 to 154,000 MHz). Between December 1998 and April 2000, displacement activity and spatial preferences were registered daily by triangulation, according to a White \& Garrot (1990) procedure.

The data were analyzed using Tracker 1.1 and TrackerMap 1.0 software, 1:10.000 scale maps, and LandSat satellite images manipulated by SIG MapInfo. For this study, a data set of about three triangulations per week for each animal was collected, comprising 607 records.

\section{RESULTS}

Male M1 was released on December 22 in the Sapé-Patos floodplain. The animal was tracked through 68 weeks and wandered the four floodplains inside the Jataí Ecological Station and also the Capão-da-Cruz (privately owned) floodplain. Female F1 was released on December 24 at the same point as male M1 had been. The animal was tracked for 9 weeks and remained almost throughout the entire period within the Sapé-Patos floodplain, except for a few days spent at the edge of the cerrado. She died on March 6. Female F2 was released on December 27 on the Sapé-Patos floodplain, 840m distant from the other release point. The animal, who died on May 15, was tracked for 19 weeks and wandered the three floodplains inside the protected area. Female F3 was released on December 29 at the same point at which female F2 had been. The animal was tracked for 68 weeks and roamed two floodplains inside the protected area and also within the Capão-da-Cruz (privately owned) floodplain. Male M2 was released on December 31 at the same point as had been females F2 and F3. He was tracked for 68 weeks and roamed two floodplains inside the protected area and also the Capão-daCruz (privately owned) floodplain.

TABLE 1

Physical dimensions of the floodplains of the study area.

\begin{tabular}{|c|c|c|c|}
\hline Floodplains & Area (ha) & Perimeter $(\mathbf{k m})$ & Average widht $(\mathbf{k m})$ \\
\hline Sapé-Patos & 129 & 7 & 0,71 \\
\hline Beija-Flor & 75 & 11 & 0,20 \\
\hline Cafundó & 143 & 9 & 0,40 \\
\hline Infernão-Óleo & 190 & 9 & 0,97 \\
\hline Total & $\mathbf{5 3 7}$ & $\mathbf{3 6}$ & $\mathbf{x}$ \\
\hline Capão-da-Cruz & 1,512 & 50 & 1,75 \\
\hline Total & $\mathbf{2 , 0 4 9}$ & $\mathbf{8 6}$ & $\mathbf{x}$ \\
\hline
\end{tabular}


Considering the total triangulation data set (607), the percentage of use of the floodplains was directly proportional to the floodplain size: Capãoda-Cruz (1,512 ha), 54\%; Infernão-Óleo (190 ha), 16\%; Cafundó (143 ha), 16\%; Sapé-Patos (129 ha), $7 \%$; and Beija-Flor (75 ha), 3\%.

Considering the triangulation records for each animal separately, the percentage of use of the floodplains showed the same tendency: male M1 (183): Capão-da-Cruz (55\%), Cafundó (27\%), BeijaFlor (11\%), Sapé-Patos (4\%); female F1 (23): SapéPatos (83\%); Female F2 (56): Cafundó (80\%), Sapé-Patos (13\%); female F3 (173): Capão-da-Cruz (63\%), Infernão-Óleo (32\%), Sapé-Patos (2\%); male M2 (172): Capão-da-Cruz (68\%), Infernão-Óleo (25\%), Sapé-Patos (3\%).

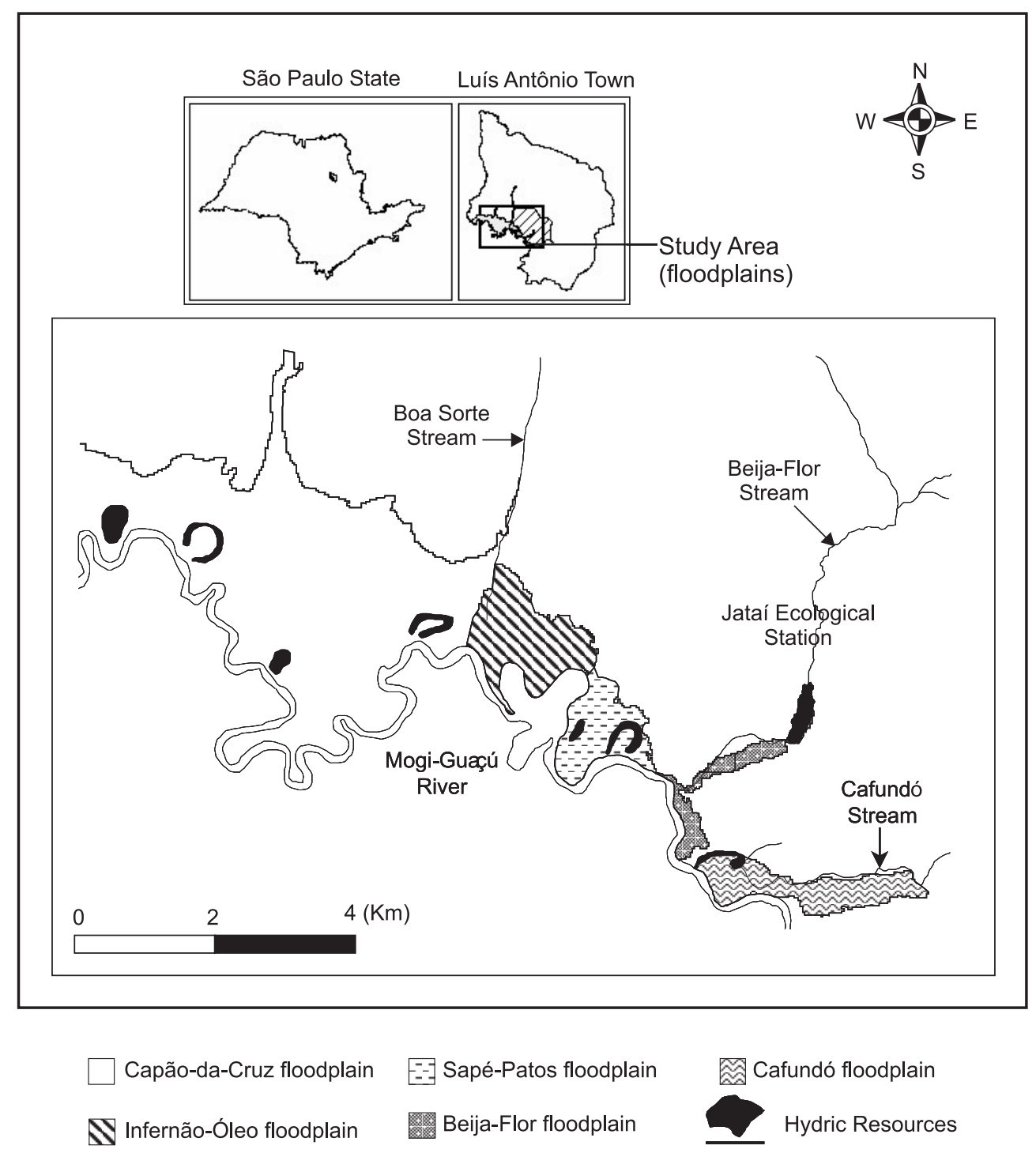

Fig. 1 - Localization of the study area in São Paulo State. 
Few triangulations out of the floodplains (cerrado, sugarcane plantation, and other sites) were registered during the study, so $96 \%$ of the total data set taken into account represented triangulations of the animals in the floodplain areas.

The percentages of animal use of the flood plains and other sites can be seen in Fig. 2 .

The displacement and approximate time spent by the animals exploring the floodplains is shown by the following sequences: male M1, Sapé-Patos (1 week) $\rightarrow$ Beija-Flor (4 weeks) $\rightarrow$ Cafundó (17.5 weeks $) \rightarrow$ Beija-Flor (6.5 weeks) $\rightarrow$ Sapé-Patos (days) $\rightarrow$ Infernão-Óleo (days) $\rightarrow$ Capão-da-Cruz (38 weeks); female F1, Sapé-Patos (9 weeks); female F2, Sapé-Patos (1 week) $\rightarrow$ Beija-Flor (days) $\rightarrow$ Cafundó (17.5 weeks); female F3, Sapé-Patos (days) $\rightarrow$ Infernão-Óleo (days) $\rightarrow$ Capão-da-Cruz (21 weeks) $\rightarrow$ Infernão-Óleo (6.5 weeks) $\rightarrow$ Capãoda-Cruz (9 weeks) $\rightarrow$ Infernão-Óleo (11 weeks) $\rightarrow$ Capão-da-Cruz (19.5 weeks); male M2, Sapé-Patos (days) $\rightarrow$ Infernão-Óleo (days) $\rightarrow$ Capão-da-Cruz (26 weeks) $\rightarrow$ Infernão-Óleo (3 weeks) $\rightarrow$ Capãoda-Cruz (15 weeks) $\rightarrow$ Infernão-Óleo (6 weeks) $\rightarrow$ Capão-da-Cruz (17 weeks).

A diagram showing the displacement direction of the reintroduced animals is presented in Fig. 3.

\section{DISCUSSION}

The severe flooding of the Mogi-Guaçú river in January and February 1999 provided a strong stimulus to the reintroduced marsh deer to wander through their new environment, since the part of the floodplains next to the river was completely submerged (especially the Sapé-Patos floodplain). Nevertheless, even during the peak of the flood the animals stayed mainly inside the floodplains limits.

Along the study period all the floodplains inside the Jataí Ecological Station and also the Capão-daCruz private floodplain were roamed by at least one of the reintroduced marsh deer. In spite of the different survival times of the animals, females F1 and F2 remained inside the Jataí Ecological Station while males M1 and M2 and female F3 left the protected area limits during their exploratory activities.

Direction chosen after release was random, with animals going towards the southeast and northwest direction no matter the release point (except for female F1). On the other hand, a spatial preference pattern emerged, since the animals roaming the floodplains preferred larger areas. Thus, female F2 and male M1 displaced at first in a southeasterly direction but settled in the Cafundó floodplain, while female F3 and male M2 initially displaced in a northwesterly direction and then settled in the Capão-da-Cruz floodplain. Later, male M1 displaced in a northwestern direction, went through all floodplains inside the Jataí Ecological Station, and also settled in the Capão-da-Cruz floodplain.

Males M1 and M2 and female F3 (animals tracked throughout the study period) were the basis for $87 \%$ of the total data set considered. Since the selection of appropriate habitats apparently represents an example of innate behavior (Harris, 1952), the spatial preferences presented by these animals suggest that the most suitable floodplain for marsh deer in the study area is the Capão-da-Cruz (privatelyowned), which besides being the last large regional floodplain, includes the largest gallery forest area. This unanimous preference by the marsh deer studied confirms the ecological importance of this area for maintaining reintroduced marsh deer.

Considering the density of between 0.5 and 1 individual $/ \mathrm{km}^{2}$ calculated for both the marsh deer population of Port Primavera (Pinder, 1996; Andriolo et al., 2001) and that of the region of Rio Negro, Miranda, and Paraguay rivers in the Brazilian Pantanal (Mauro, 1993), the carrying capacity of the Capão-da-Cruz floodplain would be between 7.6 and 15.1 individuals $/ \mathrm{km}^{2}$, while that of the floodplains of the protected area would be between 2.6 and 5.3 individuals $/ \mathrm{km}^{2}$.

During the study period, intensive use was observed of the Capão-da-Cruz floodplain by many other animal species, numerous of which are on the list of species threatened with extinction in São Paulo State (São Paulo, 1998). The frequent observation of these animal species, reinforced by the preference for this area presented by the surviving reintroduced marsh deer, reveals the ecological importance of the Capão-da-Cruz floodplain for the region. Therefore, we strongly suggest that the acquisition and incorporation of Capão-da-Cruz floodplain to the Jataí Ecological Station, as referred to in the management plan proposed by Pires (1999) be upgraded from "priority" to "high priority". 
Reintroduction is considered one of the means to manage populations threatened with extinction, as well as an important conservation strategy provided that certain guidelines are followed (Kleiman, 1989). Particularly in the case of ungulates, reintroduction shares common features, and information gathered from projects involving species of this group can serve as models for future projects (Van Dierendonck \& Wallis de Vries, 1996). In the case of marsh deer, such information is increasing and is a potentially valuable source in planning further reintroduction programs involving Brazilian ungulate species.

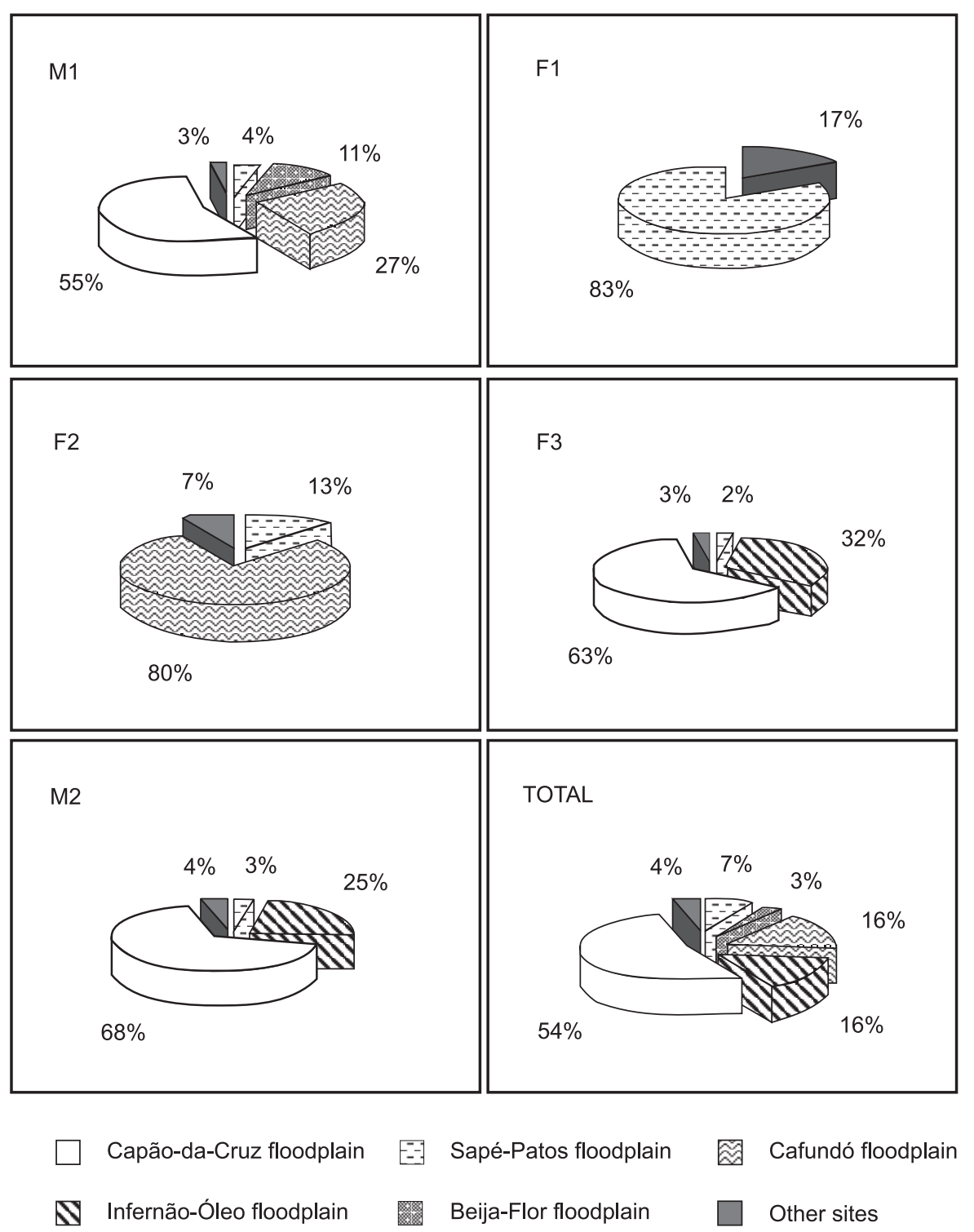

Fig. 2 - Percentages of use of the floodplains and other sites based on the triangulations records for the reintroduced marsh deer. 


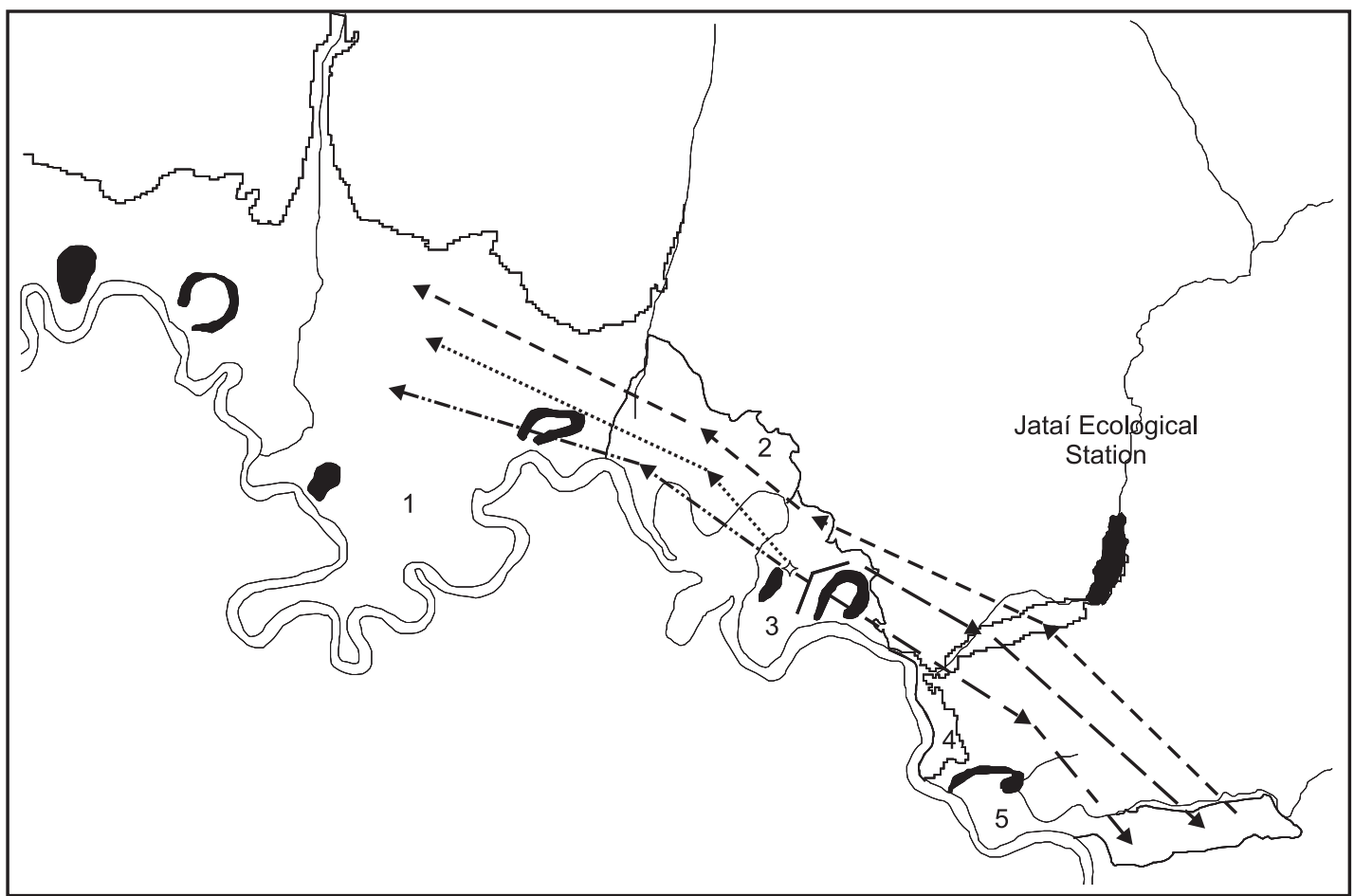

$\diamond$ Release point

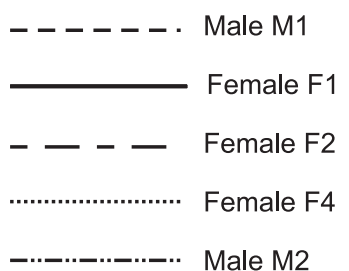

$$
\begin{aligned}
& \text { 1- Capão-da-Cruz floodplain } \\
& 2 \text { - Infernão-Óleo floodplain } \\
& \text { 3-Sapé-Patos floodplain } \\
& 4 \text { - Beija-Flor floodplain } \\
& 5 \text { - Cafundó floodplain }
\end{aligned}
$$

Fig. 3 - Illustrative diagram showing the displacement direction of the reintroduced marsh deer.

Acknowledgements - The authors are grateful to the researchers Alexandre dos Santos Bastos, Hermógenes Aparecido Torres, and Fernanda Maria Neri for collaborating in data collection; Antônio Carlos S. Zanato, director of Luís Antônio Experimental Station and Jataí Ecological Station, for his support; the Instituto Florestal for permission to carry out this study in the Jataí Ecological Station; Companhia Energética de São Paulo (CESP) for financial support of the Projeto Cervo-do-Pantanal de Porto Primavera; Instituto Brasileiro do Meio Ambiente (IBAMA) for animal capture and transport permissions; the residents and employees of Luís Antônio Experimental Station and Jataí Ecological station for their collaboration and hospitality.

\section{REFERENCES}

ANDRIOLO, A., PIOVEZAN, U., PARANHOS DA COSTA, M. J. R., LAAKE, J. \& DUARTE, J. M. B., 2001, Estimativa aérea de abundância e distribuição do cervo-do-pantanal (Blastocerus dichotomus) na bacia do rio Paraná, entre as barragens de Porto Primavera e Jupiá em avaliações pré e pós enchimento da primeira cota da U. H. E. Sérgio Mota. In: J. M. B. Duarte (coord.), O Cervo-do-Pantanal (Blastocerus dichotomus) de Porto Primavera. CD-ROM, Funep, Jaboticabal. 
AZARA, F., 1902, Apuntamientos para la historia natural de los quadrúpedes del Paraguay y Rio de Plata. Imprenta de la Viuda de Ibarra, Madrid, v. 1, pp. 1-389.

BECCACECI, M. D., 1994, A census of marsh deer in Iberá Natural Reserve, its Argentine stronghold. Oryx, 28: 131-134.

BERNARDES, A.; MACHADO, A. B. M. \& RYLAND, A. B., 1990, Mammalia. In: Fundação Biodiversitas, Fauna brasileira ameaçada de extinção. Belo Horizonte. 62p.

BLACKARD, J., 1971, Restoration of white-tailed deer in the Southwestern United States. M. S. Thesis. Lousiana State University, Baton Rouge, Lousiana, 167p.

CABRERA, A., 1961, Catálogo de los mamíferos de América del Sur. Revista del Museo Argentino de Ciencias Naturales Bernardino Rivadavia, 4: 309-732.

CAMPBELL, S., 1980, Is reintroduction a realistic goal? In: M. E. Soulé \& B. A. Wilcox (eds.), Cons. Biology. Sinauer Associates, Inc., Sunderland, MA, pp. 263-269.

CONSEMA, 1985, Áreas Naturais do Estado de São Paulo. SP, CONSEMA, 16p.

CONWAY, W. G., 1980, An overview of captive propagation. In: M. E. Soulé \& B. A. Wilcox (eds.), Cons. Biology. Sinauer Associates, Inc., Sunderland, MA, pp. 199-208.

DUARTE, J. M. B., 1996, Guia de identificação de cervídeos brasileiros. FUNEP, Jaboticabal, 14p.

DUARTE, J. M. B. \& MERINO, M. L., 1997, Taxonomia e evolução. In: J. M. B. Duarte (ed.), Biologia e conservação de cervídeos sul-americanos: Blastocerus, Ozotoceros $\mathrm{e}$ Mazama. FUNEP, Jaboticabal, SP, pp. 1-21.

GREEN, W. C. H. \& ROTHSTEIN, A., 1998, Translocation, hybridization and the endangered black-faced impala. Cons. Biology, 12(2): 475-480.

GRIBEL, R., 1993, Os mamíferos silvestres e as grandes barragens na Amazônia. In: J. G. Ferreira, G. M. Santos, E. L. M. Leão \& L. A. Oliveira (eds.), Bases científicas para estratégias de preservação e desenvolvimento da Amazônia. Instituto Nacional de Pesquisas da Amazônia, Manaus, Brazil, 21: 125133.

HARRIS, V. T., 1952, An experimental study of habitat selection by prairie and forest races of the deermouse, Peromyscus maniculatus. Contr. Lab. Vert. Biol., University of Michigan, 56: $1-53$

HOFMAN, R. C., PONCE DEL PRADO, C. F. \& OTTE, K. C., 1976, Registrato de dos nuevas especies de mamíferos para el Perú, Odocoileus dichotomus (Iiliger, 1811) y Chrysocyon brachyurus (Iiliger, 1811), con notas sobre su habitat. Rev. Florestal del Perú, 5: 61-81.

INTERNATIONAL UNION FOR CONSERVATION OF NATURE AND NATURAL RESOURCES, 1984, The IUCN position statement on translocation of living organisms: introductions, reintroductions and re-stocking. IUCN, Final Draft.

JUNGIUS, H., 1976, Status and distribution of threatened deer speciess in South America. Report to the SSC/IUCN Deer Specialist Group. Reprinted from the World Wildlife Yearbook, pp. 203-217, 1975-1976.
KLEIMAN, D. G., 1989, Reintroduction of captive mammals for conservation. BioScience, 39(3): 152-161.

MAURO, R. A., 1993, Abundância e padrão de distribuição de cervo-do-pantanal Blastocerus dichotomus (Illiger, 1811) no Pantanal Matogrossense. Master Thesis, Universidade Federal de Minas Gerais, 48p.

MILLER, F. W., 1930, Notes on some mammals of southern Mato Grosso, Brazil. J. Mammal., 11: 10-22.

NOGUEIRA NETO, P., 1973, A criação de animais indígenas vertebrados. Tecnapis, São Paulo, p. 291-295.

PINDER, L., 1996, Marsh deer (Blastocerus dichotomus) population estimate in the Paraná river, Brazil. Biol. Conservation, 75: 87-91.

PIRES, A. M. Z. C. R., 1999, Diretrizes para a conservação da biodiversidade em planos de manejo de unidades de conservação. Caso de estudo: Estação Ecológica de Jataí e Estação Experimental de Luís Antônio (Luís Antônio-SP). Doctor Thesis, PPG-ERN, UFSCar, São Carlos, 208 p.

RIBEIRO, A., 1919, Veados do Brasil segundo as coleções Rondon e de vários museus nacionais e estrangeiros. Rev. do Museu Paulista, 11: 213-308.

SÃO PAULO - SMA, 1998, Secretaria de Estado do Meio Ambiente. Fauna ameaçada no Estado de São Paulo. Secretaria de Estado do Meio Ambiente, São Paulo: SMA/ CED, 56p.

SCHALLER, G. B. \& VASCONCELOS, J. M., 1978, A marsh deer census in Brazil. Oryx, 14: 345-351.

SIOLI, H., 1986, Sensitive habitats: threats and management - tropical continental aquatic habitats. In: M. E. Soulé (ed.), Conservation biology: the science of scarcity and diversity. Sinauer, Sunderland, MS, USA, pp. 383-393.

TOMAS, W. M., 1986, Observações preliminares sobre a biologia do cervo-do-pantanal, Blastocerus dichotomus Illiger, 1811 (Mammalia, Cervidae) no Pantanal de Poconé, MT. Monografia, Universidade Federal de Mato Grosso, Instituto de Biociências, Cuiabá, MT, 55p.

TOMAS, W. M., 1991, Comportamento do cervo-do-pantanal. Anais do X Encontro de Etologia, Unesp, Jaboticabal, pp. 163-166.

TOMAS, W. M., BECCACECI, M. D. \& PINDER, L., 1997, Cervo-do-Pantanal. In: J. M. B. Duarte (ed.), Biologia e conservação de cervídeos sul-americanos: Blastocerus, Ozotoceros e Mazama. FUNEP, Jaboticabal, SP, pp. 24-38.

VAN DIERENDONCK, M. C. \& WALLIS DE VRIES, M. F., 1996, Ungulate reintroductions: experiences with the Takhi or Przewalski Horse (Equus ferus przewalskii) in Mongolia. Cons. Biology, 10(3): 728-740.

WHITE, G. C. \& GARROT, R. A., 1990, Analysis of wildlife radio-tracking data. Academic Press, San Diego, California, $383 \mathrm{p}$. 